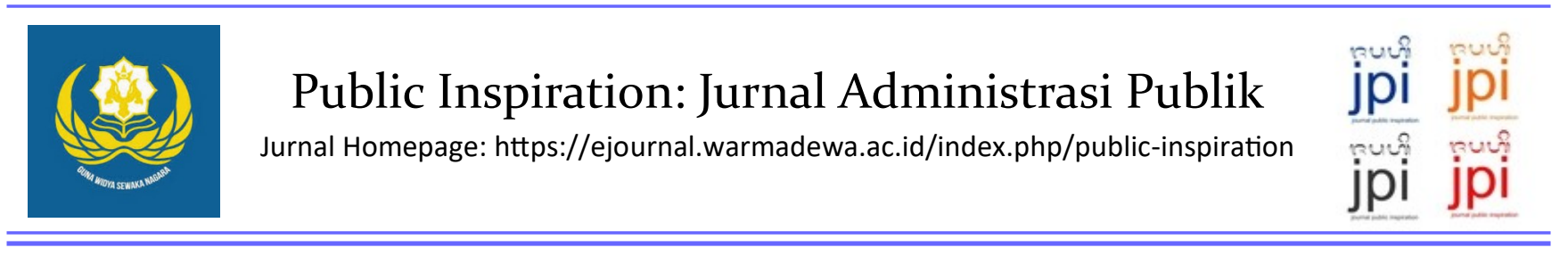

\title{
Perizinan Usaha Industri Dagang Depot Air Minum di Kota Denpasar
}

\author{
I Nengah Suriata \\ Sekolah Tinggi Ilmu Sosial Politik Wira Bhakti, Denpasar-Indonesia \\ Corespondence E-mail: nengahsuriataı@gmail.com
}

How to Cite: Suriata, I. N. (2021). Perizinan Usaha Industri Dagang Depot Air Minum di Kota Denpasar. Public Inspiration: Jurnal Administrasi Publik, 6(1). 42-54. DOI: https://doi.org/10.22225/pi.6.1.2021.42-54

\begin{abstract}
Water is very necessary in human life, so the use of water needs to be regulated properly. Water pollution will affect the quality of human life in the environment where they live. Nowadays water has economic value, despite the abundant existence on this earth, except for critical and barren areas. Most people are inefficient in regulating water so that it will endanger human life and the environment. The state of waste in using water at the Water Depot, as a refill for people's drinking needs, needs to be regulated in legal regulations. This water research is entitled Trade Industry Business Licensing for Drinking Water Depot in Denpasar City. This study aims to regulate the licensing of the Water Trading Depot in Denpasar City, so that the water produced has a health standard quality and is not harmful to consumers. While the theory used to discuss the concept of rule of law and theory of authority. This research uses a normative method, through the approach of applicable laws and regulations, as well as primary and secondary and tertiary sources of material. The results of this study indicate that water is very much needed to regulate it through various laws and regulations ranging from laws, government regulations, ministerial regulations as well as regional regulations and regulations of the Mayor of Denpasar. The regulation of water that has economic value can be morally and socially responsible. It is suggested that water regulation can be regulated by the community in the city of Denpasar based on local genenius wisdom.
\end{abstract}

Keywords: Licensing; drinking water industry business

\begin{abstract}
Abstrak
Air sangat diperlukan dalam kehidupan manusia, sehingga penggunaan air perlu diatur dengan sebaik-baiknya. Pencemaran air akan mempengaruhi kualitas hidup manusia dalam lingkungan tempat tinggalnya. Dewasa ini air memiliki nilai ekonomis, walaupun keberadaan melimpah ruah di bumi ini, kecuali daerah kritis dan tandus. Kebanyakan masyarakat tidak efisien dalam mengatur air sehingga akan membahayakan bagi kehidupan manusia dan lingkungannya. Keadaan pemborosan dalam menggunakan air pada Depot Air, sebagai isi ulang bagi kebutuhan minum masyarakat perlu diatur dalam perangkat peaturan hukum. Penelitian air ini dengan judul Perizinan Usaha Industri Dagang Depot Air Minum di Kota Denpasar. Penelitian ini bertujuan untuk mengatur perizinan Depot Perdagangan Air di Kota Denpasar, agar air yang dihasilkan memiliki mutu standar kesehatan dan tidak membahayakan bagi konsumen. Sedangka teori yang dipergunakan untuk membahas yaitu Konsep Negara Hukum dan Teori Kewenangan. Metode penelitian yang digunakan yaitu penelitian normatif, melalui pendekatan peraturan perundang-undang yang berlaku, serta sumber bahannya baik primer dan sekunder serta tersier. Hasil penelitian ini bahwa, air sangat diperlukan pengaturannya melalui berbagai peraturan perundang-undangan mulai dari undang-undang, peraturan pemerintah, peraturan menteri serta peraturan daerah serta peraturan Walikota Denpasar. Pengaturan air yang bernilai ekonomi dapat dipertanggungjawab secara moral dan sosial. Disarankan pengaturan air dapat diatur oleh masyarakat di kota Denpasar berdasarkan kearifan loka (local genenius).
\end{abstract}

Kata kunci: Perizinan; usaha industri air minum 


\section{Pendahuluan}

Keberadaan perkembangan Pemerintahan Daerah dalam sistem pemerintahan negara Indonesia seiring dengan situasi sosial politik Perkembangan itulah melahirkan Undang-Undang Republik Indonesia Nomor 23 Tahun 2014 Tentang Pemerintahan Daerah, (UU 23/2014). Sistem pemerintahan sejak kelahiran Negara Indonesia sudah dirumuskan dengan desentralisasi.

Berdasarkan atas desentralisasi, maka Pemerintah Daerah Kabupaten/Kota memiliki kewenangan untuk mengurus dan mengatur semua urusan pemerintah, kecuali yang ditentukan sebagai urusan Pemerintah Pusat. Sesuai dengan Pasal 10 ayat (1), UU 23/014, disebutkan urusan pemerintahan yang menjadi pemerintah, meliputi ; politik luar negeri, pertahanan, keamanan, yustisi , moneter dan fiskal nasional;dan agama. Sedangkan Pasal 12 ayat (3) huruf f dan huruf g, urusan pemerintahan yang menjadi kewenangan yaitu bidang perdagangan dan perindustrian.

Pelayanan umum dibidang perizinan merupakan bentuk tindakan pemerintah daerah dalam upaya untuk memberikan pelayanan serta penyelenggaraan urusan pemerintahan di daerah. Oleh karena itu, maka perizinan merupakan urusan dalam penyelenggaraan pemerintahan yang berdasarkan ketentuan peraturan perundang-undangan menjadi urusan pemerintah daerah. Kewenangan pemerintah daerah dalam bidang perizinan, meeupakan fungsi bagi pemerintah daerah.

(Ridwan, 2006) menyebutkan, bahwa fungsi perizinan sebagai suatu instrumen, izin berfungsi selaku ujung tombak instrumen hukum sebagai pengarah, perekayasa, dan perancang masyarakat adil dan makmur. Hal ini lewat izin dapat dketahui bagaimana gambaran masyarakat adil dan makmur itu terwujud. Sedangkan menurut Prajudi Atmosudirdjo dalam (Ridwan, 2006), berkenaan fungsi-fungsi hukum modern, izin dapat diletakkan dalam fungsi menertibkan masyarakat.

Fungsi perizinan oleh pemerintah, sesuai dengan pendapat N.M. Spel dan J.B.J.M. Ten Berge dalam (Utama, 2007), ada 5 (lima) hal yang mendasari. Adapun kelima motif atau tujuan diikatkannya suatu tindakan tertentu melalui instrumen perizinan adalah :

- keinginan mengarahkan (mengendalikan "sturen”) aktifitas-aktifitas tertentu;

- untuk mencegah bahaya bagi lingkungan (izin -izin lingkungan);

- keinginan melindungi obyek-obyek tertentu (izin tebang, izin membongkar pada monumenmonumen);

- hendak membagi benda-benda yang sedikit (izin penghuni di daerah padat penduduk);

- pengarahan, dengan menyeleksi orang-orang dan aktifitas-aktifitas.

Berkenaan fungsi perizinan oleh pemerintah, maka perizinan diperlukan pengaturan lebih lanjut bagi kewenangan pemerintah dalam melakukan tindakan sesuai dengan prinsip legalitas. Kewenangan menurut Prajudi Atmosudirdjo dalam (Utama, 2007) menyebutkan bahwa, kewenangan (authority gezag) adalah apa yang disebut "kekuasaan formal, kekuasaan yang berasal dari kekuasaan legislatif (diberi oleh undang-undang ) atau dari kekuaaan legislatif administratif. Kewenangan dimaksud biasanya sendiri terdiri atas beberapa wewenang (kekuasaan terhadap segolongan orang- orang tertentu atau kekuasaan terhadap sesuatu bidang pemerintahan atau bidang urusan) tertentu yang bulat, sedangkan wewenang hanya mengenai sesuatu onderdil tertentu saja.

Kewenangan tindakan pemerintah yang berasal dari kekuasaan legislatif sebagai pembentuk undang-undang, maka diterbitkan UU 23/2014, tentang Pemerintahan Daerah . Kewenangan menurut pendapat Soewoto dalam (Utama, 2007) dibedakan atas 2 (dua) macam yakni pemberian kuasa (Mandaatsverlening) dan pendelegasian (Delegatie). Atas dasar pembagian tersebut maka hubungan antara pemerintah pusat dengan pemerintah daerah dapat dikualifikasikan menjadi 2 (dua) macam yakni : 
- hubungan dalam kaitannya dengan pelaksanaan desentralisasi ;

- hubungan yang berkaitan dengan pelaksanaan dekonsentralisasi dan tugas pembantuan.

Hubungan yang berkaitan dengan perizinan oleh pemerintah daerah, sesuai dengan hubungan yang bersifat vertikal yaitu pemerintah pusat memberikan pendelegasian penyelenggaraan urusan pelayanan umum dibidang pengeloaan perizinan di daerah. Pemerintah Pusat sesuai dengan prinsip desentralisasi, berdasarkan Pasal 1 angka 7 UU 23/2014 menyebutkan, desentralisasi adalah penyerahan urusan pemerintahan oleh pemerintah pusat kepada daerah otonom berdasarkan asas otonomi. Dan Pemerintah Daerah menurut bunyi Pasal 1, angka 6, menyebutkan Otonomi daerah adalah hak, wewenang dan kewajiban daerah otonom untuk mengatur dan mengurus sendiri urusan pemerintahan dan kepentingan masyarakat setempat dalam sistem Negara Kesatuan Republik Indonesia. Dengan memahami bunyi pasal tersebut, maka kewenangan untuk mengatur dan mengurus di bidang pemerintahan khususnya pengelolaan perizinan terletak pada pemerintahan daerah. Kewenangan yang dimiliki oleh Pemerintah Daerah lebih luas dalam mengatur daerahnya masingmasing sesuai dengan kondisi dan potensi yang dimiliki.

Sesuai dengan kewenangan pemerintah daerah untuk mengatur daerahnya, maka Pemerintah daerah Kota Denpasar menerbitkan Peraturan Daerah Kota Denpasar Nomor : 12 Tahun 2002 Tentang Ijin Usaha Industri (IUI) (Perda 12/2002). Dalam konsideransi menyebutkan bahwa usaha-usaha industri dan perdagangan merupakan salah satu sektor kehidupan dalam perekonomian rakyat yang perlu dibina, dikembangkan dan dikendalikan, baik dalam perencanaan maupun dalam kegiatan usahanya sehingga dapat memberikan hasil guna dan daya guna bagi pembangunan di Kota Denpasar. Dijelaskan lebih lanjut berdasarkan Pasal 1 huruf k, yang dimaksudkan dengan Ijin Usaha Industri yang selanjutnya disingkat IUI adalah Surat Ijin untuk dapat melaksanakan kegiatan usaha industri. Pasal 1 huruf m, menyebutkan bahwa Perusahaan Industri adalah perusahaan yang melakukan kegiatan dibidang usaha industri yang dapat berbentuk perorangan, perusahaan, persekutuan atau badan hukum.

Pada saat ini kebutuhan akan air sangat meningkat seiring jumlah populasi jumlah penduduk di Kota Denpasar. Makin banyak penduduk, maka kebutuhan akan air bersih yang memenuhi standar kesehatan akan menjadi lebih banyak jumlahnya. Kebutuhan air bersih dan sehat menyebabkan makin banyak orang untuk berusaha industri dagang Depot Air Minum. Untuk itu diperlukan suatu peraturan -perundangan untuk mengatur, agar terwujud tingkat kewajaran berusaha yang baik dalam suatu wilayah di Kota Denpasar.Oleh karena itu, maka Pemerintah Daerah Kota Denpasar mengeluarkan Peraturan Daerah Kota Denpasar Nomor 4 Tahun 2003 Tentang Retribusi Perijinan Di Bidang Kesehatan, sebagai sarana untuk mengatur dan mengurus pemerintahan Kota Denpasar dibidang kesehatan.

Dalam kontek pelayanan umum bagi masyarakat Kota Denpasar, maka Pemerintah Kota Denpasar memiliki fungsi untuk mengatur dan mengurus dalam rangka untuk mewujudkan kesejahteraan bagi warga masyarakat. Fungsi mengatur yang dilaksanakan oleh Pemerintah Kota Denpasar adalah dalam rangka untuk melaksanakan negara hukum (rechtsstaat) dan negara kesejahteraan (welfare state). Kebebasan untuk melakukan berusaha bagi warga masyarakat Kota Denpasar merupakan salah satu upaya untuk meningkatkan kesejahteraan bagi masyarakat. Usaha Industri dagang Depot Air Minum yang berada dalam kawasan Kota Denpasar salah satu upaya mensejahterakan warga Kota Denpasar, maka perlu diatur lebih lanjut, dalam bentuk pemberian perizinan usaha Industri dagang Depot Air Minum .

\section{Rumusan Masalah.}

Perizinan yang dikeluarkan oleh Kota Denpasar meliputi perizinan Usaha Kecil dan Menengah diantaranya, Perizinan Usaha Industri Dagang Depot Air Minum. Dalam penelahan permasalahan perizinan di Kota Denpasar, fokus permasalahan diletakkan pada: 
Bagaimana bentuk, serta hak dan kewajiban perizinan usaha industri perdagangan Depot Air Minum di Kota Denpasar?

Bagaimana penegakkan hukum atas pelanggaran hak dan kewajiban perizinan usaha industri perdagangan Depot Air Minum di Kota Denpasar?

\section{Landasan Teoritis}

Untuk membahas permasalahan yang telah dikemukan pada rumusan masalah tersebut diatas, maka akan diketengahkan beberapa konsep dan teori hukum maupun pandangan para sarjana atau doktrin sebagai pembenaran teoritik yang relevan dengan permasalahan yang dibahas. Untuk itu teori yang digunakan terdiri dari konsep negara hukum, dan teori wewenang.

\section{Konsep Negara Hukum}

Berdasarkan pendapat Aristoteles yang dikutip dari Azhary dalam (Ridwan, 2006), menyebutkan tentang negara hukum yakni suatu negara yang baik ialah negara yang diperintah dengan konstitusi dan berkedaulatan hukum. Ada tiga unsur dari pemerintahan yang berkonstitusi yaitu pertama, pemerintahan dilaksanakan untuk kepentingan umum; kedua, pemerintahan dilaksanakan menurut hukum yang berdasarkan pada ketentuan -ketentuan umum, bukan hukum yang dibuat secara sewenang-wenang yang menyampingkan konvensi dan konstitusi; ketiga, pemerintahan berkonstitusi berarti pemerintahan yang dilaksanakan atas kehendak rakyat, bukan berupa paksanaan , tekanan yang dilaksanakan pemerintahan despotik. Dalam kaitannya dengan konstitusi, Aristoteles mengatakan bahwa konstitusi merupakan penyusunan jabatan dalam suatu negara dan menentukan apa yang dimaksud dengan badan pemerintahan dan apa akhir dari setiap masyarakat. Selain itu, konstitusi merupakan aturan-aturan dan pengusas harus mengatur negara menurut aturan -aturan tersebut.

Begitu pula menurut pendapat Burkens, negara hukum (rechtsstaat) adalah negara yang menempatkan hukum sebagai dasar kekuasaan dan penyelenggaraan kekuasaan tersebut dalam segala bentuknya dilakukan di bawah kekuasaan hukum.

Dalam konsep Negara hukum ,dengan munculnya konsep rechtstaat dari Freidrich Julius Stahl, yang dilhami oleh Immanuel Kant. Menurut Stahl, unsur-unsur Negara hukum (rechtsstaat) adalah :

- perlindungan hak- hak manusia;

- pemisahan atau pembagian kekuasaan untuk menjamin hak-hak itu;

- pemerintahan berdasarkan peraturan perundang - undangan dan

- peradilan administrasi dalam perselisihan.

Sedangkan menurut A.V Dicey dalam (Ridwan, 2006), konsep Negara hukum (rule of law), mengemukakan unsur-unsur rule of law pada intiny a sebagai berikut :

- Supremasi aturan- aturan hukum (supremacy of the law).

- Kedudukan yang sama dalam menghadapi hukum (equality before the law) .

- Terjaminnya hak- hak manusia oleh undang-undang.

Menurut (Hadjon, 1987) mengemukakan negara hukum Indonesia yang berdasarkan Pancasila, memiliki ciri -ciri sebagai berikut :

- keserasian hubungan antara pemerintah dan rakyat berdasarkan asas kerukunan;

- hubungan fungsional yang proposional antara kekuasaan-kekuasaan negara;

- prinsip penyelesaian sengketa secara musyawarah dan peradilan merupakan sarana terkhir;dan 
Public Inspiration: Jurnal Administrasi Publik, 6 (1) (2021), 46

Perizinan Usaha Industri Dagang Depot Air Minum di Kota Denpasar

keseimbangan antara hak dan kewajiban.

Negara hukum berarti negara yang berdasarkan hukum. Oleh karena itu negara hukum menggunakan asas "legalitas" (legaliteits beginsel), yang merupakan salah satu prinsip utama yang dijadikan sebagai dasar dalam penyelenggaran pemerintahan dan kenegaraan di setiap negara hukum terutama bagi negara -negara hukum dalam sistem kontinental.

Konsep Negara hukum Indonesia dalam sistem pemerintahan Negara ditegaskan pada penjelasan Undang-Undang Dasar 1945 sebelum Amandemen, dinyatakan bahwa Negara Indonesia berdasarkan atas hukum (Rechtsstaat), tidak berdasarkan kekuasaan belaka (Machtsstaat). Dalam arti bahwa setiap tindakan pemerintah maupun tindakan rakyat didasarkan atas hukum untuk mencegah adanya tindakan kesewenang-wenangan dari penguasa. Begitu pula Negara Hukum dalam sistem Pemerintahan Republik Indonesia telah dicantumkan dalam Pasal 1 ayat (3) hasil Amandemen UUD NRI 1945 yang ketiga yang berbunyi sebagai berikut :

"Negara Indonesia adalah Negara hukum." Undang-Undang Dasar 1945, menjamin adanya hak asasi manusia, prinsip-prinsip peradilan yang bebas dan tidak memihak yang menjamin persamaan setiap warga Negara dalam hukum, serta menjamin keadilan bagi setiap orang termasuk terhadap penyelenggaraan wewenang oleh pihak yang berkuasa. Negara Indonesia secara konstitusional merupakan negara hukum yaitu Negara Hukum berdasarkan Pancasila, maka Negara Republik Indonesia merupakan Negara Hukum Pancasila. Negara Hukum Pancasila adalah Negara didalam mengambil tindakan pemerintah berdasarkan atas hukum untuk mensejahterakan masyarakat yang didalamnya mengandung nilai-nilai setiap sila dari kelima sila Pancasila. Dengan demikian, maka Pancasila merupakan sumber hukum dari segala sumber hukum Negara Indonesia. Mengacu dari konsep negara hukum dengan permasalahan yang dibahas, maka asas legalitas yang merupakan tindakan pemerintah berdasarkan atas peraturan perundang -undangan yang berlaku.

\section{Teori Kewenangan.}

Dalam teori kewenangan selalu digunakan dalm hukum publik, sehingga berdasarkan atas , pendapat Henc van Maarseveen sebagaimana dikutif oleh Hadjon dalam (Sadjijono, 2008) bahwa Teori Kewenangan, digunakan di dalam hukum publik yaitu, wewenang terdiri atas sekurangkurangnya tiga komponen yaitu : pengaruh, dasar hukum dan konformitas hukum. Komponen pengaruh, ialah bahwa penggunaan wewenang dimaksudkan untuk mengendalikan prilaku subjek hukum. Komponen dasar hukum bahwa wewenang itu harus ditunjuk dasar hukumnya, dan komponen komformitas hukum mengandung adanya standar wewenang, yaitu itu standard umum (semua jenis wewenang), dan standard khusus (untuk jenis wewenang tertentu). Pada konsep wewenang pemerintahan (bestuursbevoegdheid), tidak semua komponen wewenang yang ada dalam hukum publik, karena wewenang hukum publik memiliki cakupan luas tidak hanya wewenang membuat keputusan (besluit) tetapi semua wewenang dalam penyelenggaraan tugas pemerintahan.

Dalam penyelenggaraan tindakan pemerintah, didasarkan atas norma wewenang yang menjadi dasar keabsahan atas tindakan pemerintahan. Wewenang yang diproleh dari peraturan perundangundangan merupakan legalitas formal yang memberi legitimasi terhadap tindakan pemerintahan yang merupakan sustansi dari asas legalitas adalah wewenang, yakni wewenang yang diproleh dari peraturan perundang-undanga, sesuai dengan prinsip negara hukum yang meletakkan undang-undang sebagai sumber kewenangan yang tidak dapat dipisahkan dengan asas legalitas. Dengan demikian, maka sumber kewenangan dapat diproleh pejabat atau badan adminstrasi negaradengan cara atribusi, delegasi dan mandat.

Kewenangan atribusi merupakan kewenangan asli atas dasar ketentuan yang diberikan oleh Undang-Undang Dasar atau Undang-Undang kepada organ negara. Delegasi sebagai pelimpahan kewenangan dari pejabat atau badan pemerintahan kepada pejabat atau badan pemerintahan lainnya, sehingga pendelegasian kepada orang yang diberikan delegasi, disebut "delegataris" melaksanakan 
Public Inspiration: Jurnal Administrasi Publik, 6 (1) (2021), 47

Perizinan Usaha Industri Dagang Depot Air Minum di Kota Denpasar

tindakan atas namanya sendiri dan bertanggung jawab sendiri. Sedangkan "mandat" tidak terjadi peralihan kewenangan, tetapi pemberi mandat , disebut "mandatory" membuat suatu keputusan atau mengambil tindakan pemerintah atas namanya ,"A.n".

Menurut pendapat H,D van Wijk/Willem Konijnenbel dalam (Sadjijono, 2008) wewenang pemerintahan diproleh dari tiga cara, yakni atributie, delegatie dan mandaat. Atributie: toekening van een bestuurbevoegdheid door een wetgever aan een bestuursorgaan; delegatie : overdracht van een bevoegdheid van het ene berstuursorgaan aan een ander; mandaat : een bestuurorgaan laat zijn bevoegheid namenshem uitoefenen door een ander, (Atribusi adalah pemberian wewenang pemerintahan oleh pembuat undang-undang kepada pemerintahan; delegasi adalah pelimpahan wewenang pemerintahan dari satu organ pemerintahan kepada organ pemerintahan lainnya; mandat adalah terjadi ketika organ pemerintahan lain atas namanya).

Menurut pendapat (Hadjon, et al, 2005), bahwa pemerintah dasar untuk melakukan perbuatan publik adalah adanya kewenangan yang berkaitan suatu jabatan (ambt). Jabatan memproleh wewenang melalui tiga sumber yakni: atribusi, delegasi dan mandat akan melahirkan kewenangan (bevoegdheid, legal power, competence). Sedangkan menurut F. A. M. Stroink dan dan J.G. Steennbeek, sebagaimana dikutip (Sadjijono, 2008) menyatakan bahwa, hanya ada dua cara organ pemerintahan memperoleh wewenang, yakni atribusi dan delegasi. Atribusi berkenaan dengan penyerahan suatu wewenang baru, sedangkan delegasi adalah menyangkut pelimpahan wewenang dari wewenang yang telah ada. Kewenangan memiliki kedudukan penting dalam kajian hukum tata negara dan hukum administrasi, sehingga kedudukan kewenangan, lebih lanjut disebutkan oleh F.A.M. Stroink dan dan J.G. Steennbeek dalam (Ridwan, 2006), sebagai konsep ini dalam hukum tata negara dan hukum administrasi, "Het begrip bevoegdheid is dan ook een kernbegrip in het staats en administratif recht.

\section{Metode}

Penelitian menggunakan metode normatif, dengan pendekatan perundang undangan yang berkaitan peraturan yang mengatur perizinan, Peraturan Daerah Kota Denpasar, Keputusan Walikota Denpasar, serta sumber bahan primer terdiri dari Undang-Undang Dasar Negara Republik Indonesia Tahun 1945, Undang-Undang Nomor 25 Tahun 2009 tentang Pelayanan Publik, Undang-Undang Republik Indonesia Nomor 23 Tahun 2014 tentang Pemerintahan Daerah, Peraturan Pemerintah Nomor 13 Tahun 1995 tentang Izin Usaha Industri, Peraturan Pemerintah Republik Indonesia Nomor 38 Tahun 2007 Tentang Pembagian Urusan Pemerintahan Antara Pemerintah, Keputusan Menteri Perindustrian dan Perdagangan Nomor: 651/MPP/Kep/10/2004 tentang Persyaratan teknis Depot Air Minum dan Perdagangannya, Peraturan Menteri Perindustrian Republik Indonesia Nomor : 41/MIND/PER/6/2008 tentang Ketentuan dan Tata Cara Pemberian IzinUsaha Industri dan Tanda Daftar Industri, Peraturan Daerah Kota Denpasar Nomor : 12 Tahun 2002 Tentang Ijin Usaha Industri (IUI), Peraturan Daerah Kota Denpasar Nomor: 4 Tahun 2003 Tentang Retribusi Perijinan di Bidang Kesehatan, serta bahan primer terdiri dari buku-buku perpustakaan yang berkaitan dengan perijinan serta bahan tersier berupa kamus, ensiklopedia.

\section{Hasil dan Pembahasan}

\section{Kedudukan perizinan usaha perdagangan Depot Air Bersih di Kota Denpasar}

Asas legalitas merupakan dasar penyelenggaraan kenegaraan dan pemerintahan. Penyelenggaraaan kenegaraan dan pemerintahan sesuai dengan kewenangan yang diberikan Undangundang. Kemudian asas legalitas digunakan dalam bidang hukum adminsitrasi negara yang memiliki makna, "Dat het bestuur aan de wet is onderworpen (bahwa pemerintah tunduk kepada undangundang). Penerapan asas legalitas, menurut Indroharto dalam (Ridwan, 2006) akan menunjang berlakunya kepastian hukum dan kesamaan perlakuan. Kesamaan perlakuan terjadi karena setiap 
Public Inspiration: Jurnal Administrasi Publik, 6 (1) (2021), 48

Perizinan Usaha Industri Dagang Depot Air Minum di Kota Denpasar

orang yang berada dalam situasi seperti yang ditentukan dalam undang-undang itu berhak dan berkewajiban untuk berbuat seperti yang ditentukan dalam undang-undang tersebut. Sementara itu, kepastian hukum akan terjadi karena suatu peraturan dapat membuat semua tindakan yang akan dilakukan pemerintah itu dapat diramalkan atau diperkirakan lebih dahulu, maka asasnya lalu dapat dilihat atau diharapkan apa yang akan dilakukan oleh aparat pemerintahan yang bersangkutan. Dengan demikian, warga masyarakat lalu dapat menyesuaikan dengan keadaan tersebut.

Kewenangan Pemerintah Kota Denpasar tidak hanya menjaga ketertiban dan keamanan (rust en orde), tetapi juga mengupayakan kesejahteraan umum (bestuurszorg). Dalam bidang pengaturan pemerintah Kota Denpasar diberikan wewenang dalam bidang pengaturan, dari fungsi pengaturan ini muncul beberapa instrumen yuridis untuk menghadapi peristiwa yang bersifat individual dan konkrit, yaitu dalam bentuk ketetapan. Izin merupakan sebuah ketetapan, yang dikeluarkan oleh pejabat yang berwenang.

Agar penyelenggaraan negara dalam tindakan pemerintah dapat berjalan dengan baik dalam mewujudkan keadilan, maka oleh Prajudi Atmosudirdjo dalam Ridwan HR, menyebutkan persyaratan yang harus dipenuhi dalam penyelenggaraan pemerintahan, yaitu sebagai berikut :

Efektivitas, artinya kegiatannya harus mengenai sasaran yang telah ditetapkan.

Legitimas, artinya kegiatan administrasi negara jangan sampai menimbulkan heboh oleh karena tidak dapat diterima oleh masyarakat setempat atau lingkungan yang bersangkutan.

Yuridikitas, yaitu syarat yang menyatakan bahwa perbuatan para pejabat administrasi negara tidak boleh melanggar dalam arti luas.

Legalitas, yaitu syarat yang menyatakan bahwa perbuatan atau keputusan administrasi negara yang tidak boleh dilakukan tanpa dasar undang - undang (tertulis) dalam arti luas; bila sesuatu dijalankan dengan dalih "keadaan darurat" kedaruratan itu wajib dibuktikan kemudian; jika kemudian tidak terbukti, maka perbuatan tersebut dapat digugat di pengadilan.

Moralitas, yaitu salah satu syarat yang paling diperhatikan oleh masyarakat ; moral dan ethik umum maupun kedinasan wajib dijunjung tinggi; perbuatan tidak senonoh, sikap kasar, kurang ajar, tidak sopan, kata-kata yang tidak pantas, dan sebaginya wajib dihindarkan.

Efisiensi wajib dikejar seoptimal mungkin; kehematan biaya dan produktivitas wajib diusahakan setinggi-tinggi.

Teknik dan teknologi yang setinggi-tingginya wajib dipakai untuk mengembangkan atau mempertahankan mutu prestasi yang sebaik - baiknya.

Dalam menyelenggarakan urusan pemerintahan yang menjadi kewajiban daerah menjalankan otonomi seluas-luasnya untuk mengatur dan mengurus sendiri urusan pemerintahan berdasarkan asas otonomi dan tugas pembantuan. Tindakan pemerintahan daerah dalam bidang mengatur dan mengurus, maka pemerintah daerah menyelenggarakan tindakan pemerintahan yang berkedaulatan daerah sesuai dengan prinsip sistem negara kesatuan republik Indonesia. Penyelenggaraan urusan pemerintahan daerah terdiri dari urusan pemerintahan yang bersifat wajib dan pilihan. Dalam penyelenggaraan urusan pemerintah yang menjadi kewenangan Pemerintahan Daerah diatur dalam Pasal 7 PP 38/2007, berkaitan dengan pelayanan dasar. Kewenangan pemerintahan daerah dibidang perizinan yang berkaitan dengan pelayanan dasar dibidang urusan pelayanan umum, merupakan kewenangan yang berskala urusan wajib untuk kabupaten/ kota.

Mengenai penyelenggaraan kewenangan perizinan di daerah saat ini ditemukan 2 (dua) model pelayanan perizinan. Pertama, Pemerintahan Daerah yang memberikan pelayanan sebagian perizinannya dengan Sitem Satu Pintu melalui suatu Kantor Unit Pelayanan Terpadu. Dikemukakan sebagian besar karena beberapa perizinan masih ditemukan dilayani secara tersebar pada instansi 
dinas dan bagian pada sekretariat di lingkungan pemerintah daerah bersangkutan. Kedua, Pemerintah Daerah yang pelayanan perizinannya dilakukan tersebar pada beberapa instansi atau bagian kesekretariatan di lingkungan pemerintah daerah bersangkutan. Obyek perizinan yang ditetapkan di daerah, pada umumnya juga bersifat multidimensi dan dijumpai pada berbagai sektor kegiatan seperti pariwisata, perdagangan, perindustrian, perumahan, pertanahan, pertanian, pertambangan, serta perhubungan.

Secara kenyataan dapat dilihat dilapangan, bahwa izin usaha perdagangan dipersyaratkan beberapa peririzinan yang bersifat teknis serta beberapa pertimbangan -pertimbangan secara hukum. Pada prinsipnya izin merupakan keputusan pejabat/badan tata usaha negara yang berwenang, yang isinya atau substansinya mempunyai sifat izin yang berlangsung lama. Izin yang berlangsung lama, merupakan izin yang menyangkut tindakan-tindakan yang berakhirnya atau masa berlakunya relatif lama, misalnya izin usaha industri.

Perizinan Usaha Industri perdagangan Depot Air Minum di kota Denpasar, merupakan izin yang bersifat menguntungkan pada pemegang izin. Izin yang menguntung merupakan izin yang isinya mempunyai sifat menguntungkan pada yang bersangkutan. Izin yang bersifat menguntungkan isi nyata keputusan merupakan titik pusat yang memberi anugerah kepada yang berangkutan. Dalam arti yang bersangkutan diberikan hak-hak atau pemenuhan tuntutan yang tidak akan ada tanpa keputusan tersebut, misalnya SIM, SITU, SIUP dan lain - lain .

Pemerintahan Kota Denpasar dalam mengurus dan mengatur berusaha dibidang Industri perdagangan Depot Air Minum di Kota Denpasar, bersifat regulerer yakni menerbitkan Perda 12/2002. Ijin Usaha Industri (IUI) Depot Air Minum diklasifikasikan jenis usaha industri tanpa melalui Persetujuan Prinsip. Berbagai persyaratan permohonan Ijin Usaha Industri Depot Air Minum berdasarkan Pasal 12 Ayat (1) Perda 12/2002, diajukan kepada Walikota Denpasar melalui Dinas Perindustrian dan Perdagangan Kota Denpasar, dengan melampirkan:

Salinan NPWP;

Salinan KTP;

Salinan Akta Pendirian dan Perubahannya;

Salinan IMB;

Informasi pembangunan pabrik dan sarana produksi (proyek);

Salinan UKL/UPL/atau SPPL;

Salinan SITU/HO/Surat Keterangan Penyanding;

Pas Photo berwarna ukuran 3 x 4 CM.

Dari sekian persyaratan yang diwajibkan terdapat beberapa izin-izin lainnya sebagai kelengkapan yang harus dipenuhi sebagai pertimbangan -pertimbangan kelayakan, sehingga dapat Ijin Usaha Industri perdagangan Depot Air Minum diberikan kepada pemohon yang bersangkutan di Kota Denpasar. Izin -Izin yang dimaksud terdiri dari :

a. Salinan KTP;

b. Salinan IMB;

Salinan UKL /UPL/atau SPPL;

Salinan SITU/HO/Surat Keterangan Penyanding;

Dengan demikian, maka perizinan Depot Air Minum memiliki kedudukan tidak berdiri sendiri seta berada dalam kewenangan Pemerintah Daerah Kota Denpasar. Diperlukan adanya terlebih dahulu 
Public Inspiration: Jurnal Administrasi Publik, 6 (1) (2021), 50

Perizinan Usaha Industri Dagang Depot Air Minum di Kota Denpasar

izin-izin yang lainnya sebagai kelengkapan kelayakan penerbitan perizinan kepada pempohon izin.. Dengan memperhatikan bunyi pasal 12 Ayat (1), maka kedudukan perolehan perizinan Depot Air Minum di Kota Denpasar harus dilengkapi dengan izin - izin yang lainnya diantaranya sebagai berikut :

Salinan KTP.

Salinan Akta Pendirian dan Perubahannya;

Salinan IMB;

Salinaiap UKL/UPL atau SPPL;

Salinan SITU/HO/Surat Keterangan Penyanding.

\section{Penegakkan hukum atas pelanggaran hak dan kewajiban perizinan usaha perdagangan Depot Air Bersih di Kota Denpasar}

Penggunaan air baku pada Depot Air Minum distandarkan air yang berasal dari Perusahaan Daerah Air Minum.Hal ini bukan berarti air PDAM yang telah didistribusikan melalui pipa ke rumah tangga dapat digunakan sebagai bahan baku bagi Depot Air Minum di kota Denpasar, melainkan dipasok dengan standar air baku PDAM Kota denpasar. Perusahaan Daerah Air Minum di Kota Denpasar memproleh air baku dari sungai dan Air Bawah Tanah (ABT). Air sungai tukad Badung memiliki kwalitas yang sangat rendah, sehingga akan menimbulkan dampak kesehatan bagi para konsumen, yang berakibat rendah mutu air minum sehingga akan merugikan para konsumen di Kota Denpasar. Kerugian yang ditimbulkan oleh Perusahaan Industri perdagangan Depot Air Minum memberikan peluang kepada konsumen untuk menuntut secara perdata berupa ganti rugi yang diakibatkan produksi air minum serta tuntutan pidana berdasarkan Undang-Undang Nomor 8 Tahun 1999 Tentang Perlindungan Konsumen (UU 8/1999).

Negara Indonesia sebagai negara hukum, maka konsekuensi logis adalah setiap tindakan pemerintah berdasarkan ketentuan peraturan perundang-undangan yang berlaku. Pada peraturan perundang-undangan yang dibuat secara yuridis yaitu dibuat oleh pejabat yang berwenang sebagai fungsi untuk mengatur dan mengurus setiapa tindakan pemerintahan. Dalam peraturan yang mempunyai sifat untuk mengatur ketertiban berprilaku dalam masyarakat, maka sudah barang tentu diatur tentang hak dan kewajiban bagi warga negara. Hak merpakan sesuatu yang dimiliki oleh msyarakat maupun penyelenggara pemerintah. Sedangkan kewajiban merupakan sesuatu yang harus dilakukan baik oleh warga negara maupun penyelenggara pemerintahan. Antara Hak dan kewajiban sepatutnya harus diseimbangkan pelaksanaannya, sehingga akan terjadi ketertiban, ketentraman dan kedamaian bagai setiap warga negara. Dengan demikian, maka ketentuan dalam penegakan hukum telah diatur berdasarkan hukum positf, yakni diatur dalam undang-undang.

Penegakkan hukum pada berbagai peraturan perundang - undangan perizinan usaha industri pergadangan Depot Air Minum, dilakukan dengan melakukan penegakkan hukum preventif maupun refresif. Penegakan hukum melalui preventif dengan melakukan pembinaan dan pengawasan. Dalam Pasal 17 Perda 12/2002, disebutkan :

Dalam rangka pembinaan dan pengawasan Walikota Denpasar dapat mengambil tindakan berupa peringatan tertulis, pembekuan Ijin Usaha Industri dan Pencabutan Ijin Usaha Industri”. Sedangkan dalam Pasal 18 ayat (1), tindakan peringatan tertulis diberikan apabila:

Melakukan perluasan tanpa memiliki Izin Perluasan;

Belum melaksanakan pendaftaran dalam Daftar Perusahaan sebagaimana dimaksud dalam Pasal 4

Tidak menyampaiakan informasi industri sebagaimana dimaksud dalam Pasal 15 atau sengaja 
Public Inspiration: Jurnal Administrasi Publik, 6 (1) (2021), 51

Perizinan Usaha Industri Dagang Depot Air Minum di Kota Denpasar

menyampaikan informasi yang tidak benar;

Melakukan pemindahan lokasi sebagaimana dimaksud pasal 8 tanpa persetujuan tertulis dari Walikota;

Menimbulkan kerusakan dan atau pencemaran akibat kegiatan usaha industrinya terhadap lingkungan hidup yang melampaui batas baku mutu lingkungan yang ditetapkan sesuai dengan peraturan perundang-undangan yang berlaku;

Melakukan kegiatan usaha industri tidak sesuai dengan ketentuan yang ditetapkan dalam IUI yang telah diproleh;

Adanya laporan atau pengaduan dari pejabat yang berwenang ataupun pemegang Hak Atas Kekayaan Intelektual bahwa perusahaan industri tersebut melakukan pelanggaran Hak Atas Kekayaan Intelektuan seperti antara lain Hak Cipta, Hak Paten atau Hak Merek.

Sedangkan Pasal 18 ayat (2), menyebutkan bahwa peringatan tertulis diberikan kepada Perusahaan Industri sebanyak 3 (tiga) kali berturut-turut dengan tenggang waktu masing-masing 1 (satu) bulan oleh Walikota. Pembinaan dan pengawasan dibidang pembekuan ijin diatur dalam Pasal 19 ayat (1), Perda Nomor 12 Tahun 2002 tentang Ijin Usaha Industri, diberikan apabila :

Tidak melakukan perbaikan walaupun telah mendapat peringatan sebagaimana dimaksudkan dalam pasal 18;

Sedang diperiksa dalam sidang Badan Peradilan karena didakwa melakukan pelanggaran Hak Atas kekayaan Intelektual antara lain Hak Cipta, Hak Paten dan Merek.

Dalam pembekuan IUI, seperti huruf a diatas berlaku selama 6 (enam ) bulan terhitung sejak tanggal dikeluarkannya Penetapan Pembekuan kegiatan Usaha Industri,dan pada huruf $\mathrm{b}$ berlaku sampai dengan ada Keputusan Badan Peradilan yang berkekuatan tetap. Apabila dalam masa pembekuan IUI yang bersangkutan telah melakukan perbaikan-perbaikan sesuai dengan ketentuan dalam Peraturan Daerah ini maka IUI nya dapat diberlakukan kembali oleh Walikota.

Terhadap tindakan berupa Pencabutan IUI dilaksanakan berdasarkan Pasal 20 apabila:

IUI dikeluarkan berdasarkan keterangan/data yang tidak benar atau dipalsukan oleh perusahaan yang bersangkutan;

Perusahaan Industri yang bersangkutan tidak mengikuti perbaikan sesuai ketentuan yang berlaku setelah melampaui masa pembekuan sebagaimana dimaksud dalam pasal 19 Ayat (1);

Perusahaan Industri yang bersangkutan memproduksi jenis industri tidak sesuai dengan ketentan SNI wajib;

Perusahaan industri yang bersangkutan telah dijatuhi hukuman atas pelanggaran HAKI oleh Badan Peradilan yang berkekuatan hukum tetap;

Perusahaan yang bersangkutan melanggar ketentuan Peraturan Perundang - undangan yang memuat sanksi pencabutan IUI.

Ketentuan pidana yang diatur dAlam Pasal 22 adalah merupakan perbuatan pelanggaran yang diancam dengan pidana kurungan paling lama 3 (tiga) bulan atu denda paling banyak Rp.5.000.000 (lima juta rupiah) atau tindak pidana ringan (tipiring). Sedangkan pelanggaran HAKI ( Hak Cipta, Paten, dan Merek) merupakan tindak pidana murni. Berdasarkan atas ketentuan dalam Peraturan Daerah Kota denpasar Nomor12 Tahun 2002 Tentang Ijin Usaha Industri, maka penegakan hukum di bidang perizinan usaha industri perdagatngan Depot Air Minum, dilakukan pengawasan sebagai langkah preventif berdasarkan Peraturan Menteri Kesehatan Nomor : 907 /MENKES/SKNII/2007 Tentang Syarat-Syarat dan Pengawasan Kwalitas Air minum yang meliputi : 
Pengawasan terhadap Depot Air Minum meliputi penggunaan air baku, proses produksi, mesin dan peralatan serta perdagangan dilakukan secara berkala atau sewaktu-waktu diperlukan.

Pengawasan terhadap mutu produksi Depot Air Minum dilaksanakan oleh Laboratorium Pemeriksa Kualitas air yang ditunjuk Pemerintah Kabupaten /Kota atau yang terkreditasi.

Penegakan hukum izin usaha industri perdagangan Depot Air Minum sebagai tindakan refresif atau perbuatan pelanggaran yang dilakukan dengan sanksi berupa tindakan administrasi berupa :

Tegoran lisan;

Tegoran tertulis;

Penghenntian sementara kegiatan;dan

Pencabutan Izin Usaha.

Pelanggaran sanksi pidana,dengan melakukan pelanggaran terhadap kewajiban berupa:

Air minum yang dihasilkan Depot Air Minum wajib memenuhi persyaratan air minum yang memenuhi standar kesehatan;

Air baku yang digunakan Depot Air Minum harus memenuhi standar mutu;

Depot harus melakukan pengawasan secara periodik terhadap mutu air baku yang ditunjuk dengan hasil uji laboratorium dan pemasok;

Depot Air Minum wajib memeriksa wadah yang dibawa konsumen dan dilarang mengisi wadah yang tidak layak pakai;

Depot Air Minum harus melakukan pembilasan dan atau pencucian dan atau sanitasi wadah dan dilakukan secara benar;

Depot Air Minum diperbolehkan menyediakan wadah tidak bermerek atau wadah polos;

Tutup wadah yang disediakan oleh Depot Air Minum harus polos/tidak bermerk;dan

Depot Air Minum tidak diperbolehkan memasang segel/"shrink wrap" pada wadah. berikut :

Jenis sanksi pidana yang berupa tindak pidana tersebut diatas, dapat dikatagorikan sebagai

a. Terhadap pelanggaran huruf a dan b dikenakan sanksi berdasarkan Undang -Undang Republik Indonesia Nomor 5 Tahun 1989 tentang Perindustrian;

b. Pelanggaran pada huruf c dikenai sanksi Pasal 62 Ayat (1) Undang-Undang Republik Indonesia Nomor 8 Tahun 1999 Tentang Perlindungan Konsumen.

c. Pelanggaran huruf d dan e dikenakan Pasal 55 Undang-Undang Republik Indonesia Nomor 7 Tahun 1996 Tentang Pangan.

d. Pelanggaran pada huruf f, g dan h dikenai sanksi pasal 90 atau 91 pada Undang-Undang Republik Indonesia Nomor 15 Tahun 2001 Tentang Merek.

Dalam penegakkan hukum, berdasarkan pasal Bab VII Perda 12/2002 disebutkan Pembinaan dan Pengawasan. Pada pasal 17, dinyatakan bahwa pembinaan dan pengawasan dapat dilakukan dengan mengambil tindakan peringatan tertulis, pembekuan Ijin Usaha Industri dan Pencabutan Ijin Usaha Industri. Peringatan tertulis berdasarkan pasal 18 dapat berupa :

Melakukan perluasan tanpa memilki izin perluasan;

Belum melakukan pendaftaran dalam Daftar Perusahaan sebagaimana dimaksud dalam Pasal 14; 
Public Inspiration: Jurnal Administrasi Publik, 6 (1) (2021), 53

Perizinan Usaha Industri Dagang Depot Air Minum di Kota Denpasar

Tidak menyampaikan informasi industri sebagaimana dimaksud dalam pasal 15 atau dengan sengaja menyampaikan informasi yang tidak benar;

Melakukan pemindahan lokasi sebagaimana dimaksud pasal 8 tanpa persetujuan tertulis dari Walikota;

Menimbulkan kerusakan dan atau pencemaran akibat kegiatan usaha industrinya terhadap lingkungan hidup yang melampaui batas baku mutu lingkungan yang ditetapkan sesuai dengn Peraturan Perundang - Undangan yang berlaku;

Melakukan kegiatan usaha industri tidak sesuai dengan ketentuan yang ditetapkan dalam Ijin Usaha Industri yang telah diprolehnya;

Adanya laporan atau pengaduan dari pejabat yang berwenang ataupun pemegang Hak Atas Kekayaan Intelektual bahwa perusahaan industri tersebut melakukan pelanggaran Hak Atas Kekayaan Intelektual seperti antara lain Hak Cipta, Hak Paten atau Merek.

Sanksi pembekuan Ijin Usaha Industri, sesuai Pasal 19 diberikan apabila ; tidak melakukan perbaikan walaupun telah mendapat peringatan sebagaimana dimaksud dalam pasal 18 ; dan sedang diperiksa dalam sidang Badan Peradilan didakwa melakukan pelanggaran Hak Atas Kekayaan Intelektual antara lain Hak Cipta, Hak Paten dan Merek. Pencabutan Ijin Usaha Industri sebagaimana dimaksud dalam pasal 20 sebagai berikut :

Ijin Usaha Industri dikeluarkan berdasarkan keterangan /data yang tidak benar atau dipalsukan oleh perusahaan yang bersangkutan;

Perusahaan industri yang bersangkutan tidak mengikuti perbaikan sesuai ketentuan yang berlaku setelah melampaui masa pembekuan sebagaimana dimaksud dalam pasal 19 ayat (1);

Perusahaan industri yang bersangkutan memproduksi jenis industri tidak sesuai dengan ketentuan SNI wajib;

Perusahaan industri yang bersangkutan telah dijatuhi hukuman atas pelanggaran HAKI oleh badan peradilan yang berkekuatan hukum tetap;

Perusahan yang bersangkutan melanggar ketentuan Peraturan Perundangan- undangan yang memuat sanksi pencabutan Ijin Usaha Industri.

Menurut Perda 12/2002, pada ketentuan pidana berdasarkan pasal 22, melakukan pelanggaran berdasarkan pasal $2,3,4,5,6,7,8$ dan pasal 15 yang diancam pidana kurungan paling lama 3 (tiga) bulan atau denda paling banyak Rp 5.000.000 (lima juta rupiah), serta tindak pidana ini diklasifikan sebagai perbuatan pelanggaran.

\section{Simpulan}

Dari uraian tersebut diatas, dapat diberikan kesimpulan sebagai berikut: Kedudukan perijinan Depot Air Minum merupakan kewenangan Pemerintah Daerah Kota Denpasar berdasarkan kewenangan yang diatur sesuai peraturan perundang-undangan, serta dilengkapi dengan izin-izin lainnya sebagai kelayakan pemberian izin kepada pemohon izin. Kewajiban dan hak diatur dalam Peraturan Menteri Kesehatan Nomor: 907/MESKES/SKNII/2002 tentang Syarat-Syarat Dan Pengawasan Kwalitas Air Minum. Penegakkan hukum bidang perijinan usaha dagang depot air minum berdasarkan atas peraturan perundang-undangan yang berlaku dengan selalu berpedoman kepada kesehatan lingkungan. Pengusaha agar selalu menjaga mutu produksi air dengan baik sehingga tidak akan ada tuntutan bagi masyarakat pengguna air minum yang bersih. Pengusaha Depot Air Minum selalu mengandakan pengawasan terhadapa alat produksi yang dipergunakan untuk mencegah air yang tidak sehat, dengan selalu mengadakan pemeriksaan di Laboratorium Pemerintahan Daerah Kota Denpasar atau yang telah terakreditasi. 


\section{Daftar Pustaka}

Chaidir, E. (2007). Negara Hukum,Demokrasi dan Konstelasi Ketatanegaraan Indonesia. Yogyakata: Penerbit Kreasi Total Media

Hadjon, P. M. (1987). Perlindungan Hukum Bagi Rakyat di Indonesia. Surabaya: Penerbit PT. Bina Ilmu.

Hadjon, P. M., et al. (2005). Pengantar Hukum Adminsitrasi Indonesia (Introduction to the Indonesian Adminstrative Law). Yogyakarta: Gajah Mada University Press

Keputusan Menteri Perindustrian dan Perdagangan Nomor: 651/MPP/Kep/10/2004 tentang Persyaratan teknis Depot Air Minum dan Perdagangannya.

Keputusan Menteri Perindustrian dan Perdagangan Nomor:705/MPP/Kep/11/2003 Tentang Persyaratan Teknis Industri Air Minum Dalam Kemasan dan Perdagangan.

Peraturan Menteri Kesehatan Nomor :907/MESKES/SKNII/2002 TENTANG Syarat -Syarat Dan Pengawasan Kwalitas Air Minum.

Peraturan Menteri Perindustrian Republik Indonesia Nomor: 41/M-IND/PER/6/2008 tentang Ketentuan dan Tata Cara Pemberian IzinUsaha Industri dan Tanda Daftar Industri.

Peraturan Menteri Perindustrian Republik Indonesia Nomor: 69/MIND/PER/7/2009 tentang Pemberlakuan Standar Nasional Indonesia (SNI) Air Minum Dalam Kemasan (AMDK) Secara Wajib.Peraturan Daerah Kota Denpasar Nomor:12 Tahun 2002 Tentang Ijin Usaha Industri.

Peraturan Daerah Kota Denpasar Nomor: 4 Tahun 2003 Tentang Retribusi Perijinan di Bidang Kesehatan.

Permenkes Nomor : 907/MENKES/SKNII/2002 tentang Syarat - Syarat Dan Pengawasan Kualitas Air Minum.

Ridwan, H. R. (2006). Hukum Administrasi Negara. Jakarta: PT Raja Grafindo Persada

Sadjijono. (2008). Memahami Beberapa Bab Pokok Hukum A dminsitrasi. Yogyakarta: LaksBang Pressindo,

Saleng, A. (2004). Hukum Pertambangan. Yogyakarta: Universitas Islam Indonesia

Sutedi, A. (2010). Hukum Perizinan dalam Sektor Publik. Jakarta: Penerbit Sinar Grafika

Tim Redaksi Forum Sahabat, 2010. Pedoman Praktis Mengurus Izin Industri dan Perdagangan, Penerbit Forum Sahabat, Jakarta.

Utama, A. (2007). Hukum Lingkungan Sistem Hukum Perizinan Berwawasan Lingkungan Untuk Pembangunan Berkelanjutan. Bandung: Penerbit Pustaka Sutra 